\title{
Properties of $N, N$-Bis[2-(isonicotinoyloxy)ethyl]-p-toluenesulfonamide. Structures of Its Silver(I) Complexes via Anion Effects
}

\author{
Tae Hwan Noh, Youn Jung Choi, Byung Jo Ha, ${ }^{\ddagger}$ Jong Sung Jin, ${ }^{\ddagger}$ and Ok-Sang Jung ${ }^{*}$ \\ Department of Chemisty' Pusan National University, Pusan 609-735, Korea. "E-mail: oksjung@pusanac.k \\ "Department of Dermatic Health Management, Eulii University, Seongnam 461-713, Korea \\ ${ }^{\ddagger}$ Pusan Center; Korea Basic Science Institute, Pusan 609-735, Korea \\ Received August 22, 2008
}

\begin{abstract}
$N, N$-Bis[2-(isonicotinoyloxy)ethyl]-p-toluenesulfonamide (L) as a new ligand was synthesized and characterized. The photoluminescence spectrum of $\mathrm{L}$ shows a bright blue enission at $417 \mathrm{~nm}$. The slow diffusion of an organic solution of $\mathrm{L}$ into an aqueous solution of $\mathrm{AgX}\left(\mathrm{X}=\mathrm{BF}_{4}^{-}\right.$and $\left.\mathrm{ClO}_{4}^{-}\right)$affords a metallacyclodimer consisting of $[\operatorname{Ag}(L)]_{2} X_{2}$. Each $\mathbf{L}$ acts as a bidentate fashion, and thus connects two $\mathrm{Ag}(\mathrm{I})$ ions to form the metallacyclodimer. For $[\mathrm{Ag}(\mathrm{L})]_{2}\left(\mathrm{BF}_{4}\right)_{2}$, the $\mathrm{BF}_{4}^{-}$anions are positioned around $\mathrm{Ag}(\mathrm{I})$ ion, and for $[\mathrm{Ag}(\mathrm{L})]_{2}{ }_{2}$ $\left(\mathrm{ClO}_{4}\right)_{2}$, the $\mathrm{ClO}_{4}^{-}$anions are positioned at the metallacyclodimeric ring. The delicate difference between both structures in solid state can be explained by the coordinating ability of anions.
\end{abstract}

Key Words : Anion effects, $N, N$-Bis[2-(isonicotinoyloxy)ethyl]-p-toluenesulfonanide, Crystal structures, Metallacyclodimers, Silver(I) complexes

\section{Introduction}

The control of macrocyclic rings by means of external perturbation is a hot issue in the construction of molecular machines as well as aesthetic molecules. ${ }^{1.5}$ In particular, various metallamacrocycles have been studied as important building blocks in the construction of functional supramolecular materials that can be utilized for molecular recognition, selective transformation, drug delivery systems, catalysts, storage, and biomimics. ${ }^{6.20}$ Facile synthetic methods are either the ring-expansion ${ }^{21-23}$ by means of labile metalligand coordination or the ring-formation via appropriate tectonics. ${ }^{1516-20}$ Among various metallamacrocycles, silver(I) complexes of multidentate $\mathrm{N}$-donor ligands have contributed to the synthesis of metal coordination materials such as catalysts, ${ }^{2+}$ rectangle building blocks, ${ }^{1 \$, 16}$ and task-specific topology. ${ }^{25}$ Tuning of molecular topology of polypyridyl spacers via the balance of steric and inductive effects is a very important field in metallacyclic supramolecular chemistry. ${ }^{16}$ Such polypyridyl ligands that can bridge two or more remote metal centers have been utilized in the synthesis of abiotic functional supramolecules that exhibit mixed valence, anion exchange, photoinduced electron or energy transfer, sensing, polymorphism, and magnetic exchange between paramagnetic centers. ${ }^{26-31}$ Thus, delicate design and synthesis of new tectonics is one of the most important tasks in the field of construction of functional metallacycles. Of the $\mathrm{N}$ donor ligands, some (iso)nicotinoyl-containing spacers have served as appropriate building blocks for various supramolecular materials. ${ }^{32,33}$ The (iso)nicotinoyl-containing spacers possess characteristic properties such as a potential multidentate, an $s p^{2}$ angle around $\mathrm{C}=\mathrm{O}\left(\sim 120^{\circ}\right)$, a malleable length, conformational nonrigidity, and manageable solubility.

In an effort to investigate the coordination chemistry of new $N, N$-bis[2-(isonicotinoyloxy)ethyl]-p-toluenesulfon- amide ligand, the reaction of $\mathrm{AgX}\left(\mathrm{X}=\mathrm{ClO}_{4}^{-}\right.$and $\mathrm{BF}_{4}{ }^{-}$: very similar in both volume and geometry) with the ligand was carried out. We report the properties of the new ligand, and delicate structures of its silver complexes via anion effects.

\section{Experimental}

Materials and Measurements. $\mathrm{AgX}$ salts $\left(\mathrm{X}^{-}=\mathrm{BF}_{4}{ }_{4}\right.$ and $\left(\mathrm{CO}_{4}{ }^{-}\right)$were purchased from Aldrich Chemicals, and used without further purification. Elemental microanalyses $(\mathrm{C}, \mathrm{H}$, N) were performed on crystalline samples by the Pusan Center at KBSI using a Perkin Elmer $2400 \mathrm{CHN}$ analyzer. ${ }^{1} \mathrm{H}$ IMR spectra were recorded on a Varian Mercury Plus 300 operating at $300.00 \mathrm{MHz}$, and the chemical shifts were relative to the internal $\mathrm{Me}_{4} \mathrm{~S}$. Thermal analyses were carried out under a dinitrogen atmosphere at a scan rate of $10^{\circ} \mathrm{C} /$ min using a Stanton Red Croft TG 100. Infrared spectra were obtained on a Nicolet 380 FTIR spectrophotometer with samples prepared as $\mathrm{KBr}$ pellets. The ultraviolet and photoluminescence (PL) spectra were measured using a Jasco V-570 UV-vis spectrometer and a Hitachi F-4500 fluorescence spectrophotometer, respectively.

Synthesis of $N, N$-Bis[2-(isonicotinoyloxy)ethyl]-p-toluenesulfonamide (L). Pyridine $(19.41 \mathrm{~mL}, 0.24 \mathrm{~mol})$ was added to a solution of isonicotinoyl chloride hydrochloride (21.36 g, $0.12 \mathrm{~mol}$ ) in chloroform $(150 \mathrm{~mL})$ at room temperature. Subsequently, $N, N$-bis(2-hydroxyethyl)-p-toluenesulfonamide $(12.966 \mathrm{~g}, 0.05 \mathrm{~mol})$ was added to the reaction solution, and the mixture was refluxed for $24 \mathrm{~h}$. The chloroform layer was washed successively with $0.5 \mathrm{~N} \mathrm{NaOH}$ solution and cold water. The chloroform solution was dried using magnesium sulfate and filtered. Removal of the solvent gave $N, N$-bis[(2-isonicotinoyloxy)ethyl]-p-toluenesulfonamide $(\mathbf{L})$. The product was obtained as crystalline 
solids in $83 \%$ yield. Mp. $93^{\circ} \mathrm{C} .{ }^{1} \mathrm{H}$ NMR $\left(300 \mathrm{MHz}, \mathrm{CDCl}_{3}\right.$. $\left.\mathrm{Me}_{4} \mathrm{Si}\right):=8.72(\mathrm{~d}, J=5.4 \mathrm{~Hz}, 1 \mathrm{H}), 7.73(\mathrm{~d}, J=5.8 \mathrm{~Hz}, 1 \mathrm{H})$, $7.67(\mathrm{~d}, J=8.1 \mathrm{~Hz}, 1 \mathrm{H}), 7.21(\mathrm{~d}, J=8.4 \mathrm{~Hz}, 1 \mathrm{H}), 4.51(J=$ $5.7 \mathrm{~Hz}, 2 \mathrm{H}), 3.61(\mathrm{t}, J=5.7 \mathrm{~Hz}, 2 \mathrm{H}), 2.33(\mathrm{~s}, 3 \mathrm{H}),{ }^{13} \mathrm{C} \mathrm{NMR}$ $\left(\mathrm{CDCl}_{;}, \mathrm{Me}_{4} \mathrm{Si}\right):=164.835,150.691,143.967,136.785$. $136.136,130.039,127.156,122.868,63.453,47.738,21.532$. $\mathrm{IR}\left(\mathrm{KBr}, \mathrm{cm}^{-1}\right): 1726\left(v_{\mathrm{CO}}\right)$.

$[\mathrm{Ag}(\mathrm{L})]_{2}\left(\mathrm{BF}_{4}\right)_{2}$. A dichloromethane solution of $\mathrm{L}$ was slowly diffused into a methanol solution of $\mathrm{AgBF}_{4}$ in the mole ratio of $1: 1$. Yield: $65 \%$ based on $\mathrm{Ag}(\mathrm{I})$ salt. Calcd (found) for $\mathrm{C}_{16} \mathrm{H}_{46} \mathrm{Ag}_{2} \mathrm{~B}_{2} \mathrm{~F}_{8} \mathrm{~N}_{6} \mathrm{O}_{12} \mathrm{~S}_{2}: \mathrm{C}, 41.60$ (41.20), H, 3.49 (3.38), N, 6.33 (6.20). IR $\left(\mathrm{KBr}, \mathrm{cm}^{-1}\right): v\left(\mathrm{BF}_{4}\right), 1054(\mathrm{~s})$.

$[\mathrm{Ag}(\mathrm{L})]_{2}\left(\mathrm{ClO}_{4}\right)_{2}$. The complex was prepared as the similar procedure as $[\mathrm{Ag}(\mathrm{L})]_{2}(\mathrm{BF})_{4}$. A dichloromethane solution of $\mathbf{L}$ was slowly diffused into a methanol solution of $\mathrm{AgClO}_{4}$ in the mole ratio of $1: 1$. Yield: $70 \%$ based on $\mathrm{Ag}(\mathrm{I})$ salt. Calcd (found) for $\mathrm{C}_{46} \mathrm{H}_{46} \mathrm{Ag}_{2} \mathrm{Cl}_{2} \mathrm{~N}_{6} \mathrm{O}_{20} \mathrm{~S}_{2}: \mathrm{C}, 40.82$ (39.90), H, $3.43(3.42), \times, 6.21$ (6.12). IR $\left(\mathrm{KBr}, \mathrm{cm}^{-1}\right): v$ $\left(\mathrm{ClO}_{4}\right), 1088$ (s).

X-ray Crystallography. All X-ray data were collected on a Bruker SMART automatic diffractometer with a graphitemonochromated Mo $\mathrm{K} \alpha$ radiation $(\lambda=0.71073 \AA$ ) and a CCD detector at ambient temperature. The 45 frames of two dimensional diffraction images were collected and processed to obtain the cell parameters and orientation matrix. The data were corrected for Lorentz and polarization effects. Absorption effects were corrected by the empirical $\psi$-scan method. The structures were solved by the direct method (SHELXS 97) and refined by full-matrix least squares techniques (SHELXL 97). ${ }^{3+}$ The non-hydrogen atoms were refined anisotropically, and hydrogen atoms were placed in calculated positions and refined only for the isotropic thermal factors. Crystal parameters and procedural information corresponding to data collection and structure refinement are given in Table 1.

Crystallographic data for the structure reported here have been deposited with the Cambridge Crystallographic Data Centre (CCDC-699166 and 699167). The data can be obtained free of charge via htp://winuccdc.cam.ac.uk/perl/ catreqicatreq.cgi (or from the CCDC, 12 Union Road, Cambridge CB2 1EZ, UK; fax: +44 1233 336033; e-mail: deposit@ccdc.cam.ac.uk).

\section{Results and Discussion}

Synthesis and Properties of Ligand. Reaction of $N, N$ bis(2-hydroxyethyl)-p-toluenesulfonamide with isonicotinoyl chloride hydrochloride in chloroform smoothly produces the new ligand $(\mathbf{L})$ as depicted in Scheme 1. Its composition and structure were confirmed by chemical analysis, IR, ${ }^{1} \mathrm{H}$ NMR, thermal analysis, and ${ }^{13} \mathrm{C} N M R$. The crystalline product is soluble in $N N$-dimethylformamide, dimethylsulfoxide, chloroform, and dichloromethane, but is insoluble in hexane and water. The ligand sharply melts at $95{ }^{\circ} \mathrm{C}$, and begins to decompose at $292{ }^{\circ} \mathrm{C}$ (Figure 1). The decomposed volatiles are drastically evaporated around $300{ }^{\circ} \mathrm{C}$. The photoluminescence spectrum shows that $\mathbf{L}$ is a bright blue emitting material with a peak at $417 \mathrm{~nm}$. The emission spectrum of $\mathbf{L}$ was measured in acetone (Figure 2). The solid compound also shows the blue color under the UV light as depicted in inset in the figure. About $90 \%$ of the luminescence appears at the blue region below $500 \mathrm{~nm}$, and thus $\mathrm{L}$ is a very promising candidate for a blue phosphorescent material. The blue luminescence seems to be originated from the change of $\pi-\pi^{*}$ transition in contrast to the starting material, $\quad N N$-bis(2-hydroxyethyl)-p-toluenesulfonamide,

Table 1. Crystallographic Data

\begin{tabular}{|c|c|c|}
\hline & {$[\mathrm{Ag}(\mathbf{L})] \pm\left(\mathrm{BF}_{4}\right):$} & {$[\mathrm{Ag}(\mathrm{L})]_{2}\left(\mathrm{ClO}_{4}\right)_{2}$} \\
\hline Empirical formula & $\mathrm{C}_{33} \mathrm{H}_{2} \mathrm{AgBF}_{4} \mathrm{~N}_{3} \mathrm{O}_{6} \mathrm{~S}$ & $\mathrm{C}_{33} \mathrm{H}_{33} \mathrm{AgCIN}_{3} \mathrm{O}_{10} \mathrm{~S}$ \\
\hline Fomula weight & 664.18 & 676.82 \\
\hline Wavelength & $0.71073 \AA$ & $0.71073 \AA$ \\
\hline Crystalsystem & Monoclinic & Monoclinic \\
\hline Space group & $P 2_{1} / \mathrm{c}$ & $P 2_{1} / \mathrm{c}$ \\
\hline \multirow[t]{3}{*}{ Unit cell dimensions } & $a=7.8231(6) \AA$ & $\mathrm{a}=7.8157(7) \AA$ \\
\hline & $\mathrm{b}=9.9521(7) \AA$ & $\mathrm{b}=10.0585(9) \AA$ \\
\hline & $c=32.943(2) \AA \quad \beta=94.4200(10)^{\circ}$ & $\mathrm{c}=33.015(3) \AA \quad \beta=94.060(2)^{\circ}$ \\
\hline $\mathrm{V}$ & $2557.2(3) A^{3}$ & $2588.9(4) \AA^{3}$ \\
\hline Z & 4 & 4 \\
\hline $\mathrm{D}$ (calculated) & $1.725 \mathrm{Mg} / 1 \mathrm{~m}^{3}$ & $1.736 \mathrm{Mg} / \mathrm{m}^{3}$ \\
\hline Absorption coefficient & $0.944 \mathrm{mum}^{-1}$ & $1.025 \mathrm{~mm}^{-1}$ \\
\hline$F(000)$ & 1336 & 1368 \\
\hline Crystal size & $0.20 \times 0.20 \times 0.15 \mathrm{mmm}^{3}$ & $0.20 \times 0.10 \times 0.10 \mathrm{~mm}^{3}$ \\
\hline Reflections collected & 15716 & 16201 \\
\hline Data / restraints / parameters & $5983 / 0 / 353$ & $6084 / 0 / 353$ \\
\hline Goodness-of-fit on $F^{2}$ & 1.320 & 1.050 \\
\hline Final R indices $[\mathrm{I}>2 \operatorname{sigma(I)}]$ & $R I=0.1670, w R 2=0.3104$ & $R 1=0.0977, w R 2=0.1792$ \\
\hline $\mathrm{R}$ indices (all data) & $R I=0.2180, w R I=0.3328$ & $R 1=0.2015, w R 2=0.2225$ \\
\hline Largest diff. peak and hole & 1.904 and $-2.085 \mathrm{e}^{-\AA^{-3}}$ & 1.024 and -0.993 e. $\AA^{-3}$ \\
\hline
\end{tabular}




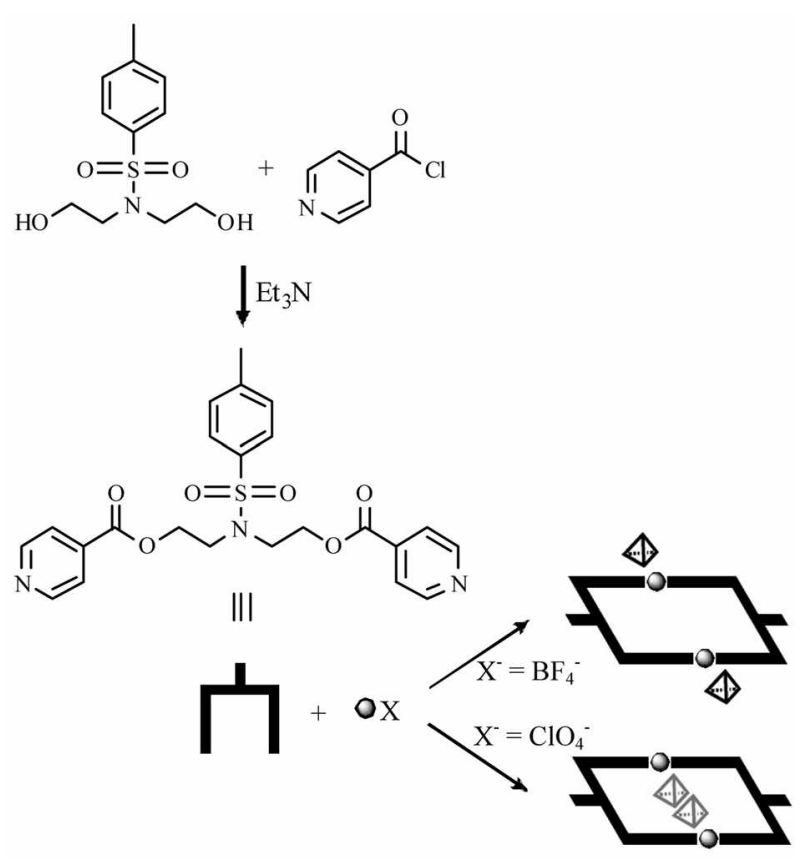

Scheme 1

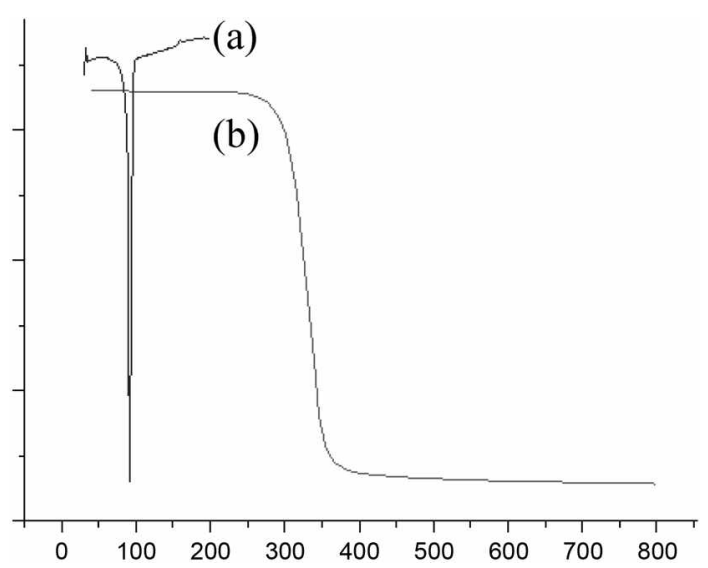

Figure 1. DSC (a) and TGA (b) of $\mathbf{L}$.

which did not show the blue luminescence.

Synthesis of Silver(I) Complexes. The slow diffusion of $\mathrm{AgX}\left(\mathrm{X}^{-}=\mathrm{BF}_{4}^{-}\right.$and $\left.\mathrm{ClO}_{+}^{-}\right)$in methanol with a potential multidentate $\mathbf{L}$ in dichloromethane produced colorless single crystals suitable for X-ray crystallography (Scheme 1). The reaction was initially carried out at the mole ratio of $1: 1$, but the same compounds were obtained irrespective of the mole ratio within the range of $\mathrm{L} / \mathrm{M}=0.5-2.5$. That is, the formation of the products was not significantly affected by the change of reactant mole ratio and concentration, indicating the compounds are favorable and thermodynamically stable species. The silver complexes are insoluble in common organic solvents, but the $\mathrm{Ag}(\mathrm{I})-\mathrm{N}$ bonds are dissociated in polar organic solvents such as dimethyl sulfoxide, $N, N$ dimethylformamide, and acetonitrile. The products are airstable, but slowly turn to gray powder under light.

Crystal Structures. Slow diffiusion of $\mathrm{AgX}$ with $\mathbf{L}$ afforded discrete silver(I) complexes in contrast to the formation of coordination polymers of general bipyridyl analogs. X-

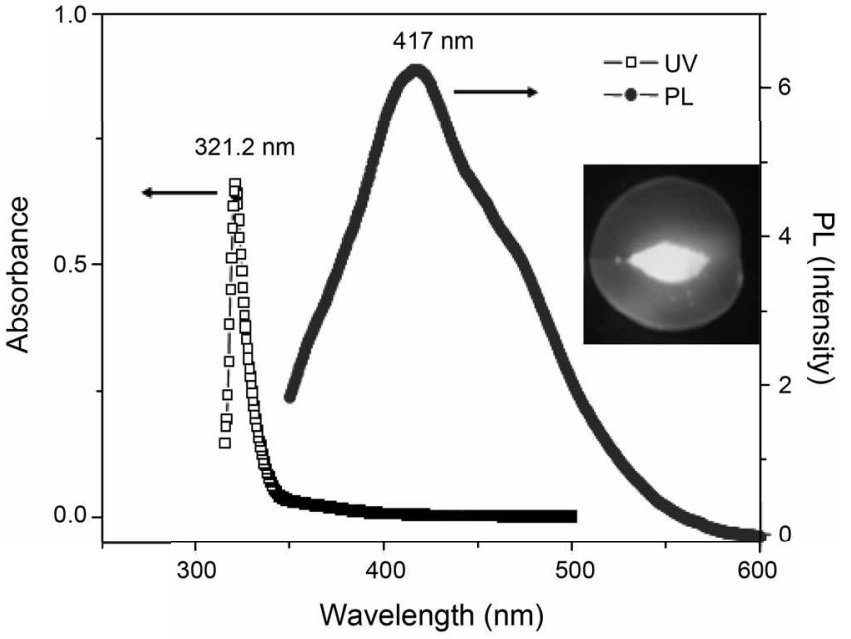

Figure 2. LV and PL spectra of $\mathbf{L}$.

(a)

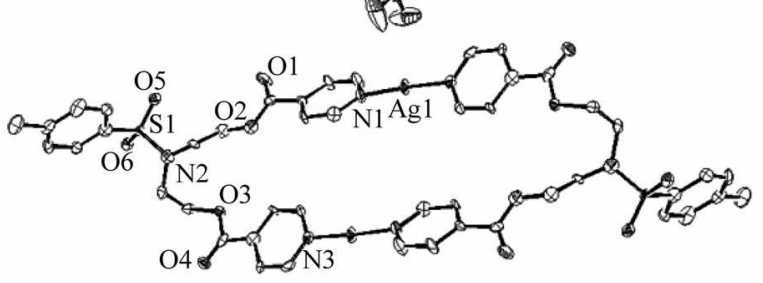

(b)

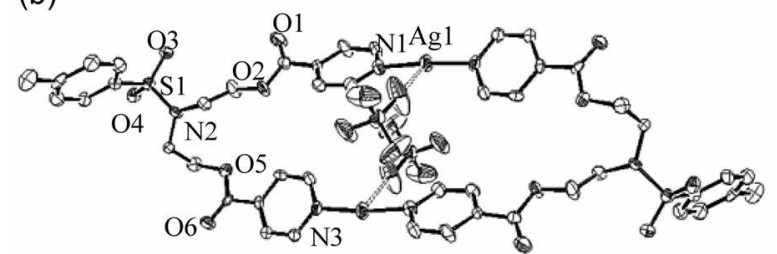

Figure 3. ORTEP drawings of $[\mathrm{Ag}(\mathbf{L})]_{2}\left(\mathrm{BF}_{4}\right)_{2}(\mathrm{a})$ and $[\mathrm{Ag}(\mathbf{L})]_{-}-$ $\left(\mathrm{ClO}_{4}\right)_{2}$ (b). Hydrogen atoms are omitted for clarity. Relevant bond lengths $(A)$ and angles $\left({ }^{\circ}\right)$ of $[\mathrm{Ag}(\mathrm{L})]_{2}\left(\mathrm{BF}_{4}\right): \mathrm{Ag}(1)-\mathrm{N}(1)=2.124$ (11). Ag( (1)-N(3) $=2.152(12) . \mathrm{N}(1)-\mathrm{Ag}(1)-\mathrm{N}(3)^{\prime}=175.8(5)$. [Ag(L)] $\left(\mathrm{ClO}_{4}\right)_{2}: \mathrm{Ag}(1)-\mathrm{N}(1)=2.148(7), \mathrm{Ag}(1)-\mathrm{N}(3)^{\prime}=2.152(7), \mathrm{Ag}(1) \cdots$ $\mathrm{O}(7)=2.717, \mathrm{~N}(1)-\mathrm{Ag}(1)-\mathrm{N}(3)^{\prime}=175.5(3), \mathrm{N}(1)-\mathrm{Ag}(1) \cdots \mathrm{O}(7)=$ $95.00 . \mathrm{O}(7) \cdots \mathrm{Ag}(\mathrm{I})-\mathrm{N}(3)^{\prime}=81.93$.

ray characterizations on single crystals have provided that the products are metallacyclodimeric species consisting of $[\mathrm{Ag}(\mathrm{L})]_{2} \mathrm{X}_{2}\left(\mathrm{X}^{-}=\mathrm{BF}_{4}^{-}\right.$and $\left.\mathrm{ClO}_{4}^{-}\right)$(Figure 3). For both complexes, $\mathbf{L}$ connects two $\mathrm{Ag}(\mathrm{I})$ ions $(\mathrm{Ag}-\mathrm{X}=2.12(1)-2.15$ (1) $\AA$ for $[\mathrm{Agg}(\mathbf{L})]_{2}\left(\mathrm{BF}_{4}\right)_{2} ; \mathrm{Ag}-\mathrm{N}=2.148(7)-2.152(7) \AA$ for $\left.[\mathrm{Ag}(\mathbf{L})]_{2}\left(\mathrm{ClO}_{4}\right)_{2}\right\}$ to form a 36-membered metallacyclodimer with two free toluenesulfonamide groups. That is, potential multidentate $\mathbf{L}$ acts as a typical bidentate fashion. The structure of $[\mathrm{Ag}(\mathrm{L})]_{2}\left(\mathrm{ClO}_{4}\right)_{2}$ is basically similar to that of $[\mathrm{Ag}(\mathrm{L})]_{2}\left(\mathrm{BF}_{4}\right)_{2}$, but the slight difference between two anions gives different packings $\left(\mathrm{Ag} \cdots \mathrm{X}=2.876 \AA\right.$ for $[\mathrm{Ag}(\mathrm{L})]_{2}-$ $\left(\mathrm{BF}_{4}\right)_{2} ; 2.718 \AA$ for $\left.[\mathrm{Ag}(\mathbf{L})]_{2}\left(\mathrm{ClO}_{4}\right)_{2}\right)$. Interestingly, the $\mathrm{ClO}_{4}{ }^{-}$ anions more closely interact with two $\mathrm{Ag}(\mathrm{I})$ ions compared to $\mathrm{BF}_{4}{ }^{-}$anions depending on the coordinating ability of the anions. The geometry around the $\mathrm{Ag}(1)$ ion of 
$[\mathrm{Ag}(\mathbf{L})]_{2}\left(\mathrm{BF}_{4}\right)_{2}$ approximates a typical linear arrangement $\left(\mathrm{A}-\mathrm{Ag}-\mathrm{N}=175.8(5)^{\circ}\right)$, and the geometry around the $\mathrm{Ag}(\mathrm{I})$ ion of $\left.[\mathrm{Ag}(\mathrm{L})]_{2}(\mathrm{ClO})_{4}\right)_{2}$ may be best described as T-shape $(\mathrm{N}-$ Ag-N $=175.5(3)^{\circ} ; \mathrm{N}(1)-\mathrm{Ag}(1) \cdots \mathrm{O}(7)=95.00^{\circ}, \mathrm{O}(7) \cdots \mathrm{Ag}(1)$ $\left.X^{\prime}(3)^{\prime}=81.93^{\circ}\right)$. Thus, For $[\mathrm{Ag}(\mathbf{L})]_{2}\left(\mathrm{BF}_{4}\right)_{2}$, the $\mathrm{BF}_{4}{ }^{-}$anions are positioned around $\mathrm{Ag}(\mathrm{I})$ ion, and for $[\mathrm{Ag}(\mathbf{L})]_{2}\left(\mathrm{ClO}_{4}\right)_{2}$. the $\mathrm{ClO}_{4}^{-}$anions are positioned at the metallacyclodimeric ring. Thus, a keen competition exists between the $\mathrm{Ag} \cdots \mathrm{X}$ and the packing diagram. The coordinating ability of two anions is well coincident with our previous order. ${ }^{35}$

Construction Principle and Related Properties. The skeleton of both complexes is a discrete metallacyclodimer. but their anion-position is strongly dependent on the nature of the anions. The formation of a metallacyclodimer may be attributed to a suitable combination of the conformer of $\mathrm{L}$ and the potential linear geometry around the $\mathrm{N}-\mathrm{Ag}-\mathrm{N}$ bonds. In particular, the complexes are exclusively constructed irrespective of the mole ratio of the reactants, the solvent types, and the concentrations.

The position and interaction of anions may be explained by the coordinating nature of anions. The $\mathrm{BF}_{4}^{-}$anion has been considered as "non-coordinating" anions compared to $\mathrm{ClO}_{+}{ }^{-}$anion. ${ }^{35}$ According to our previous results, both anions are very similar in geometry and size. ${ }^{25}$ Thus, the packing of the present products appears to be delicately associated with the coordinating nature of anions rather than size effects of anions. The formation of stable $\mathrm{Ag}-\mathrm{N}$ bonds and $\mathrm{Ag} \cdots \mathrm{X}$ interactions may be partly indebted to the electronic effects of the ligand. For the silver(I) complexes, the blue emission properties were quenched, presumably owing to the change of conformation and electronic effects

\section{Conclusion}

The new blue emitting multidentate bipyridine spacer is a fascinating tectonic in the construction of a discrete cyclodimeric skeleton without any particular strain. The anionposition of the present silver(I) complexes is a good example that the coordinating ability of anions is a very important factor for the molecular packing. The results may contribute to the development of rational bulk materials of coordination complexes.

Acknowledgments. This research was supported by a grant from the Fundamental R\&D Program for Core Technology of Materials funded by the Ministry of Knowledge Economy, Republic of Korea.

\section{References}

1. Stang, P. J.; Olenyuk, B. Acc. Chem. Res. 1997, 30, 502.

2. Beissel, T.; Powers, R. E.; Raymond, K. N. Angen: Chem., Int. Ed. 1996, 35, 1084.
3. Balladini, R.; Balzani, V.; Credi, A.; Gandolfi, M. T.; Venturi, M. Acc. Chem. Res. 2001, 34, 445 .

4. Davis, A. V; Yeh, R. M.; Raymond, K. N. Proc. Nat. Acall. Sci. 2002, 99, 4793.

5. Lehn, J.-M. Supramolecular Chemistry: Concepts and Perspectives: VCH: Weinheim, 1995

6. Swiegers, G. F.; Malefetse, T. I. Coond. Chen. Rev. 2002, 225, 91.

7. Cotton, F. A.; Lin, C.; Murillo, C. A. Acc. Chem. Res. 2001, 34, 759 .

8. Leinigner, S.; Olenyuk, B.; Stang, P. J. Chem. Rev. 2000, 100,853

9. Jude, H.; Disteldorf, H.; Fischer, S.; Wedge, T.; Hawkridge, A. M.; Arit, A. M.; Hawthome, M. F.; Muddiman, D. C.; Stang, P. J. J. Am. Chem. Soc 2005, 127, 12131.

10. Wang, P.; Moorefield, C. N.; Newkome, G. R. Angen: Chem., Int. Ed. 2005, 44, 1679 .

11. Grote, Z.; Scopelliti, R.; Severin, K. J. Am. Chem. Soc. 2004, I26, 16959

12. Benkstein, K. D.; Hupp, J. T.; Stem, C. L. J. Am. Chem. Soc. 1998, 120, 12982

13. Jung, O.-S.; Lee, Y.-A.; Kim, Y. J.; Hong, J. Cutst. Growth Des. $2002,2,497$.

14. Lehara, K.; Kasai, K.; Mizuno, N. Inorg. Chem. 2007, 46, 2563.

15. Zhang, Z.; Cai, R.; Chen, Z.; Zhou, X. Inorg. Chem. 2007, 46, 321 .

16. Jung, O.-S.; Kim, Y. I.; Lee, Y.-A ; Kang, S. W; Choi, S. N. Hong, J. Crist. Growth Dess. 2004, 4, 23.

17. Na, Y. M.; Noh, T. H.; Chun, I. S.; Lee, Y.-A.; Hong, J.; Jung, O. S. Inorg. Chem. 2008, 47, 1391 .

18. Kang, H. J.; Noh, T. H.; Jin, J. S.; Jung, O.-S. Inorg. Chem. 2008, 47,5528 .

19. Kim, S. A.; Kim, J. P.; Ahn, Y. M.; Hong, J.; Jung, O.-S. Bull. Korean Chem. Soc. 2008, 29, 729 .

20. Kim, S. A.; Yoon, H. J.; Kang, H. J.; Kim, J. P.; Jung, O.-S. Bull. Korean Chem. Soc. 2008, 29, 1266.

21. Fujita, M.; Tominaga, M.; Hori, A.; Therrien, B. Acc. Chem. Res. 2005, 38, 369 .

22. Habermehl, N. C.; Eisler, D. J.; Kirby, C. W.; Yue, N. L.-S.; Puddephatt, R. I. Organonterallics 2006, 25, 2921.

23. Fujita, M. Chem. Soc. Rev 1998, 27, 417.

24. Yao, Q.; Kinney, E. P.; Zheng, C. Org. Lett. 2004, 6, 2997.

25. Jung, O.-S.; Kim, Y. J.; Lee, Y.-A.; Park, J. K.; Chae, H. K. $J$. Am. Chem. Soc. 2000, 122, 9921

26. Catalano, V. I.; Larson, W. E.; Olmstead, M. M.; Gray, H. B. Inorg. Chen. 1994, 33, 4502 .

27. Baba, A. I.; Ensley, H. E.; Schnehl, R. H. Inorg. Chem. 1995, 34 , 1198

28. Amoroso, A. J.; Thomson, A. M. W. C.; Malher, J. P.; McCleverty, J. A.; Ward, M. D. Inorg. Chem. 1995, 34, 4828.

29. Yaghi, O. M.; Li, H.; Davis, C.; Richardson, D.; Groy, T. L. Acc. Chen. Res. 1998, 31, 474.

30. Cho, Y.; Park, Y.; Choi, W. J. Ind. Eng. Chent 2008, 14, 315.

31. Gal, Y. S.; Jin, S. H.; Lim, K. T.; Lee, W. C. J. Ind. Eng. Chem. 2005, 11,63 .

32. Chun, I. S.; Kwon, J. A.; Yoon, H. J.; Bae, M. N.; Hong, J.; Jung, O.-S. Angerv, Chem, Int. Ed. 2007, 46,4960

33. Chun, I. S.; Lee, K. S.; Hong, I.; Do, Y.; Jung, O.-S. Chem. Lett. 2007,548 .

34. Sheldrick, G. M. SHELXS-97: A Program for Structure Detenmination; Lniversity of Göttingen, Germany, 1997; Sleldrick, G. M. SHELXZ-97: A Program for Structure Refinement; Lniversity of Göttingen, Gernany, 1997.

35. Jung, O.-S.; Kim, Y. J.; Lee, Y.-A.; Park, K. M.; Lee, S. S. Inorg. Chent $2003,42,844$. 